\title{
Histo- and Cyto-pathological Alterations Induced by the New Egyptian Isolate Potyvirus on Hyocyamus muticus L. Leaves
}

\author{
Reham M. $\mathrm{Ebaz}^{1}{ }^{*}$, ET. Abd El-Salam ${ }^{2}$, M. E. Osman ${ }^{1}$ \\ and Asmaa F. Abd E-Monem ${ }^{1}$ \\ ${ }^{I}$ Botany and Microbiology Department, Faculty of Science, \\ Helwan University, ${ }^{2}$ Botany and Microbiology Department, \\ Faculty of Science, Cairo University, Cairo, Egypt.
}

\begin{abstract}
- ISTOPATHOLOGICAL and cy topahological studies on infected Hyocyamus muticus L. plants with a new potyvirus-Egyptian isolate with accession number KM497011 was investigated. The infected Hyocyamus muticus $\mathrm{L}$. showing virus-like symptoms on its leaves in the form of a net mosaic, blistering, rugosity and malformation. Histopathology of an Egyptian potyvirus isolateinfected Hyocyamus muticus L. leaves using light microscopy showed abnormal structures of the lamina, epidermal cells, mesophyll tissue and vascular bundles compared with healthy one. Cytopathology of an Egy ptian poty virus isolate-infected Hyocyamus muticus L. leaves using electron microscopy showed pinwheel and scrolls inclusion bodies and abnormal cell wall thickness, nucleus, chloroplast and no clear internal structure of mitochondria compared with healthy one. Our conclusion, the new Egyptian potyvirus isolate caused changes in the cells and tissue structure of henbane leaves as the same of other known poty virus strains.
\end{abstract}

Keywords: Hyocyamus muticus L., Potyvirus, Histopathology, Cytopathology

The genus potyvirus in the family Potyviridae is one of the largest plant virus genera. As important pathogens, potyviruses are much more studied than other plant viruses belonging to other genera and their study covers many as pects of plant virology (King et al., 2011; Revers and García, 2015) that are accounted for $40 \%$ of los ses caused by all plant viruses (Yamamoto and Fuji, 2008). Evans (2009) reported that henbane leaves consist of a broad midrib. A transverse section of a henbane leaf shows a bifacial structure with a smooth cuticle, normal epidermal cells, a large number of hairs and stomata. The broad midrib contains a bicollateral vascular bundle. The mesophyll of the midrib has two thin zones of collenchyma and a colorless parenchyma. Egyptian henbane was differentiated from Hyocyamus niger by the numerous unbranched and branched glandular trichomes, which have one- to fourcelled stalk and unicellular heads. Shukla et al. (1994) found that members of the family Potyviridae characteristically induced the formation of cytoplasmic inclusions

*Corresponding author : d.reham@ hotmail.com 
(CI) in suitable stained epidermal leaf cells, which were detectable by light microscopy. Kitajima and Lovisolo (1972) examined the thin sections of HMVinfected Datura stramonium L. leaf tissues by electron microscope, contained lamellar inclusions, which appeared as pinwheels, parallel lines, rings or arcs. In addition to, long crystalline structures arranged in a lattice in the cytoplasm of most cells. Cylindrical mitochondria tightly packed in certain areas of the cytoplasm. Between adjacent mitochondria there was a layer of elongated, virus -like particles, running parallel and longitudinally to the mitochondrial surface. Nicotiana and Datura infected by and mechanically inoculated with henbane mosaic virus had pinwheel structures typical of the potyvirus group (Horvath et al., 1988).

This investigation was carried out to study history and cytopathological alterations on Hyocyamus muticus L. leaves infected by a new Egyptian potyvirus is olate.

\section{Materials and Methods}

Plant source

Infected henbane (Hyocyamus muticus L.) leaves with a new potyvirus-Egyptian isolate (ACC. No.KM497011) and healthy one.

Histopathology of an Egyptian potyvirus isolate -infected Hyocyamus muticus L. leaves using light microscopy

Permanent slides were made in young full expanded leaves of $H$. muticus $\mathrm{L}$.

\section{The preparation of permanent slides}

The technique used for preparation of permanent slides from microtome sections were mainly those used by Johansen(1940), Sass (1951) and Purvis et al. (1964) with some modifications. It consists of the following procedures:

1. Selecting desired leaves

Healthy and virus-infected $H$. muticus L. leaves showing mosaic and blistering systemic symptoms were selected. Leaves were cut into pieces of $1 \mathrm{~cm}$.

\section{Killing, fixing and starting plant tissues.}

3. Dehydration for embedding.

Series of different concentration solutions of ethyl alcohol and tertiary butyl alcohol (TBA) were prepared.

4. Infiltration and embedding in paraffin wax.

4.1. Infiltration: Pieces of leaves were transferred to mixtures of equal parts of paraffin oil and TBA end left for an hour. A vial was filled three-fourths full of melted wax and left until the wax had solidified then covered with the butyl alcohol-paraffin oil mixture. Finally, it was replaced by a good quality of paraffin melting at $55{ }^{\circ} \mathrm{C}$ approximately.

\subsection{Casting into a mould or embedding}

Storing the cast blocks in the refrigerator for several days.

Egypt. J. Bot., 56, No. 2 (2016) 


\section{Microtome sectioning of material in paraffin.}

5.1. Adhesive

5.2. Mounting on slides: a small drop of the adhesive was placed on the slide and smeared over the surface. The slide was flooded with solution of $3 \%$ formalin distilled water before the adhesive was dry.

\section{Staining of sections:}

The lignified elements were stained red, shinning against a green background.

Cytopathology of an Egyptian potyvirus isolate-infected Hyocyamus muticus L. leaves using electron microscopy

Small pieces of healthy and virus-infected henbane leaves were cut. Then, they were fixed in $2 \%$ glutaraldhyde about $5 \mathrm{hr}$ and post-fixed in cold buffered $1 \%$ Osmium tetraoxide for 2 hours. Rinsed three times in $0.1 \mathrm{M}$ phosphate buffer, $\mathrm{pH}$ 6.8. Then, kept in uranyl acetate for $3 \mathrm{hr}$ and followed by rinsing in distilled water. After fixation, the tissue pieces were dehydrated in graded series of ethanol solution and embedded in a mixture of methacrylate-stiyrol (Stockem and Komnick, 1970).

Ultrathin sections were cut on a Reichert ultra-microtome equipped with glass knives and were stained with lead citrate for $2-5 \mathrm{~min}$. at room temperature (Reynolds, 1963).The leaves sections were examined with a Jeol-Jem 1010 Transmission electron microscope.

Plant source

\section{Results}

Hyocyamus muticus $\mathrm{L}$. leaves infected with a new Egyptian potyvirus isolate (acc. No. KM497011) showing virus-like symptoms on its leaves in the form of net mosaic, blistering, rugosity and malformation (Fig. 1).

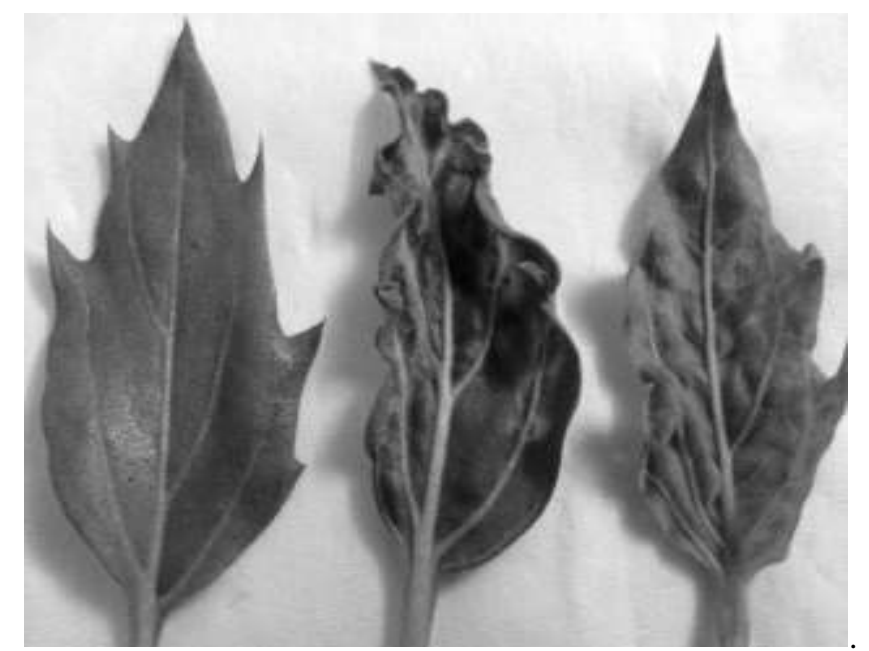

Fig.1. Hyocyamus muticus $\mathrm{L}$. leaves, the left one is healthy leaf and the others are infected leaves showing mosaic, blistering, rugosity and malformation .

Egypt. J. Bot., 56, No. 2 (2016) 
Histopathology of Hyocyamus muticus L. leaves infected with an Egyptian potyvirus isolate using light microscopy

Healthy leaf

The lamina of healthy leaf is nearly flat and hairy with slightly bulging midrib from the upper and lower sides (Fig. 2). Homogenous mesophyll tissue with somewhat compact cells and no clear differentiation into palisade and spongy tissues, the most are palaside tissue (Fig.3). Upper and lower epidermal cells are barrel-shaped and have few stomata with clear stomatal chamber (Fig. 4). The midrib contains a usual bicollateral vascular bundle with very clear xylem rows have moderate lignifications. The upper and lower phloem arranged in clear patches (Fig.5).

\section{Infected leaf}

The lamina of infected leaf is mostly irregular with clearly huge and irregular bulging midrib. Upper and lower epidermal cells are smaller and compact than healthy ones. Also, the blade becomes unequal thickness (Fig.6).Somewhat increase in number of stomata and substomatal chamber. Substomatal chamber appears wider and disrupted. Mesophyll tissue shows abnormal clear aerenchyma (Fig.7).In some parts, mesophyll tissue appears compact and spongy tissues between with very clear upper and lower palaside layers. In few parts, compact mesophyll tissue shows no differentiation (Fig.8).The midrib contains somewhat flat or slightly curved bicollateral vascular bundle. The vascular bundle has haphazard arranged xylem vessels(vertical and horizontal). Xylem vessels are nearly few and reduced in size, the newly formed vessels are less lignified. Upper and lower phloem patches not clearly recognized. The vascular bundle also shows abnormal necrotic tissues (Fig.9). Parenchyma cells surrounding the vascular bundle are abnormally large with clear wavy wall (Fig.10).

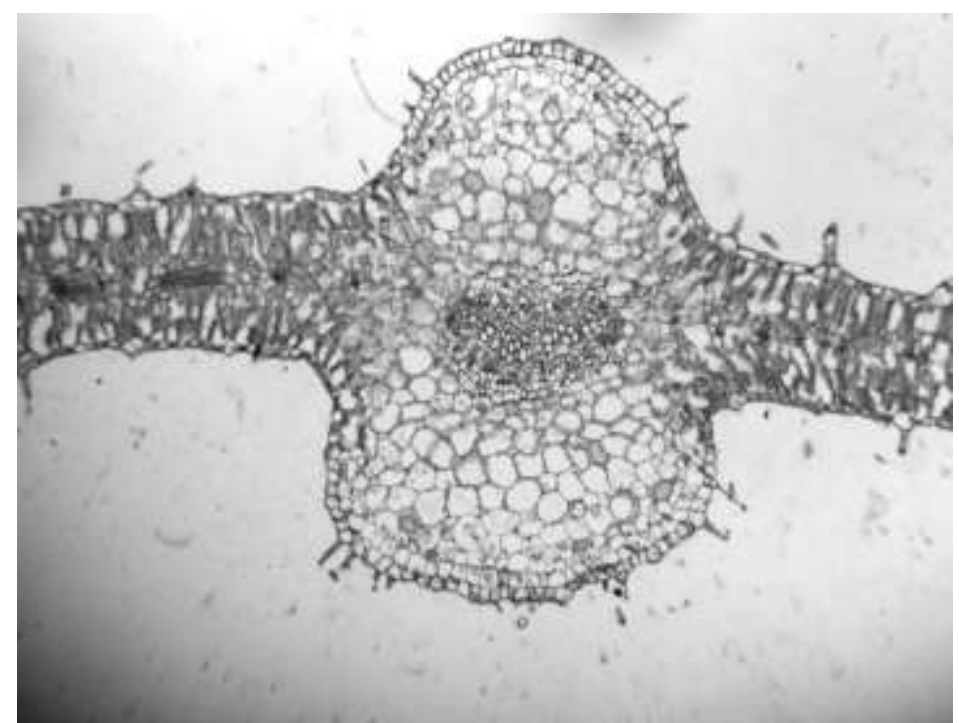

Fig. 2. Light microscope study of section of healthy leaf showing nearly flat of lamina with slightly bulging midrib from the upper and lower sides (Mag. 4X) .

Egypt. J. Bot., 56, No. 2 (2016) 


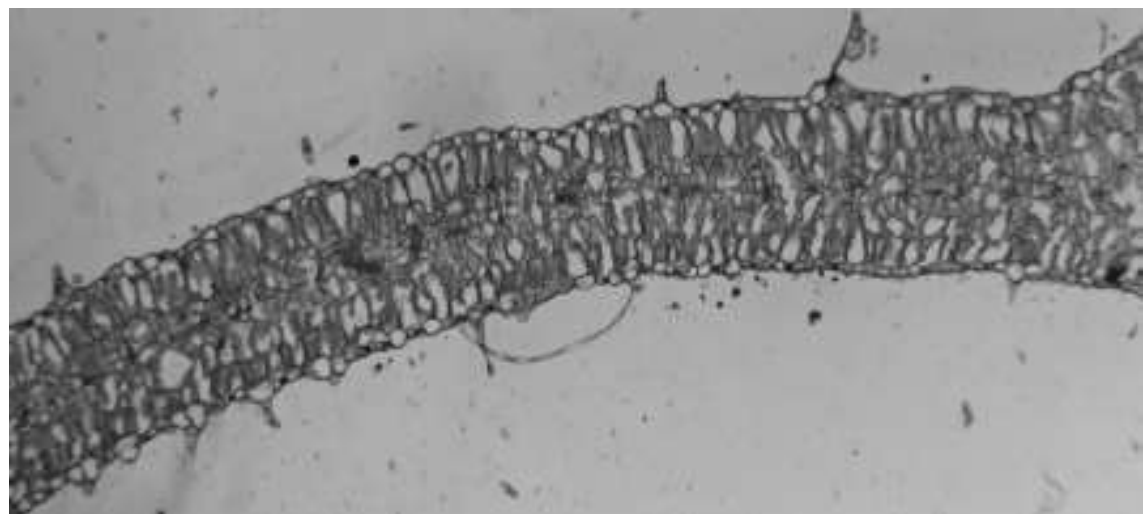

Fig.3. Light microscope study of section of homogenous mesophyll showing clear undifferentiating between palaside and spongy tissues in healthy leaf (10X).

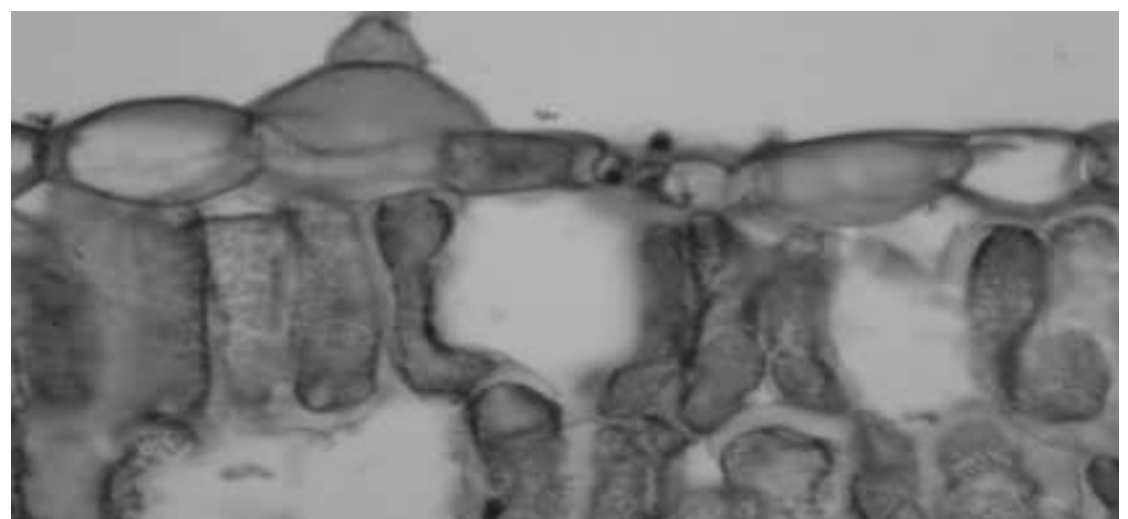

Fig.4. Light microscope study of section of healthy leaf showing normal stomata with clear stomatal chamber $(40 \mathrm{X})$.

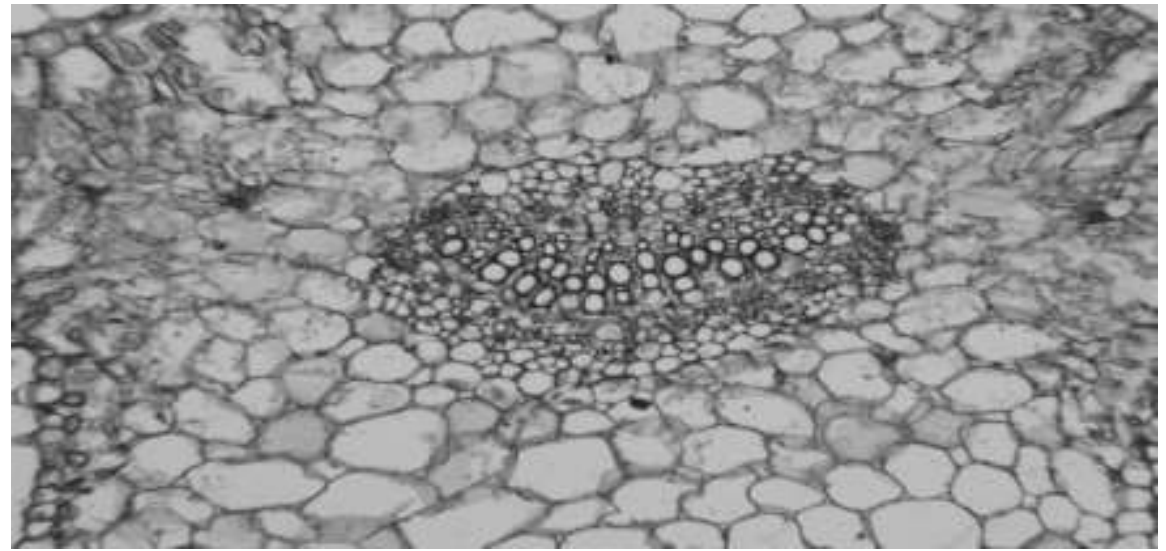

Fig.5. Light microscope study of section of healthy leaf showing crescent -shaped collateral vascular bundle (10X). 


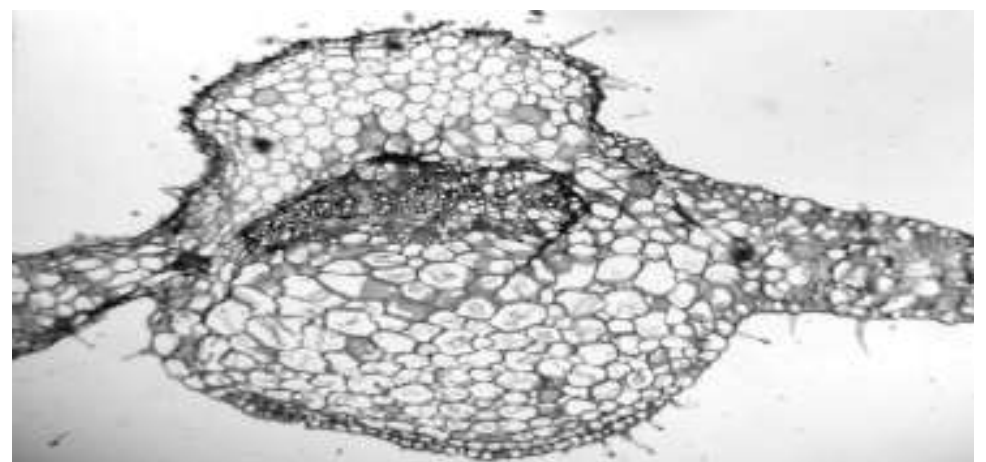

Fig.6. Light microscope study of section of infected leaf showing irregular leaf lamina and clearly bulging upper and lower sides $(4 \mathrm{X})$.

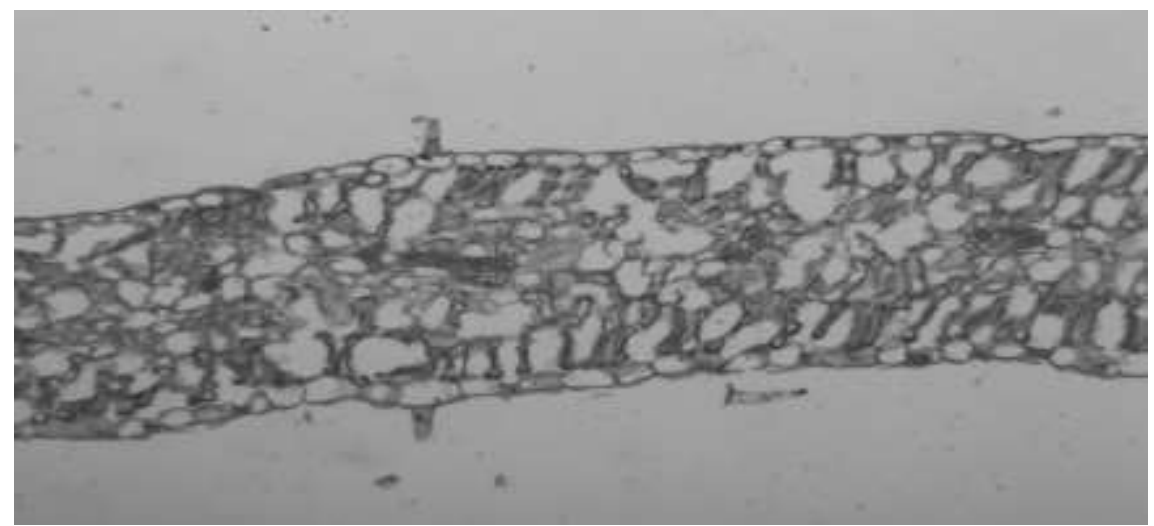

Fig.7. Light microscope study of section of infected leaf showing disintegrated stomatal chamber compared and abnormal clear aerenchyma at mesophyll tissue (10X).

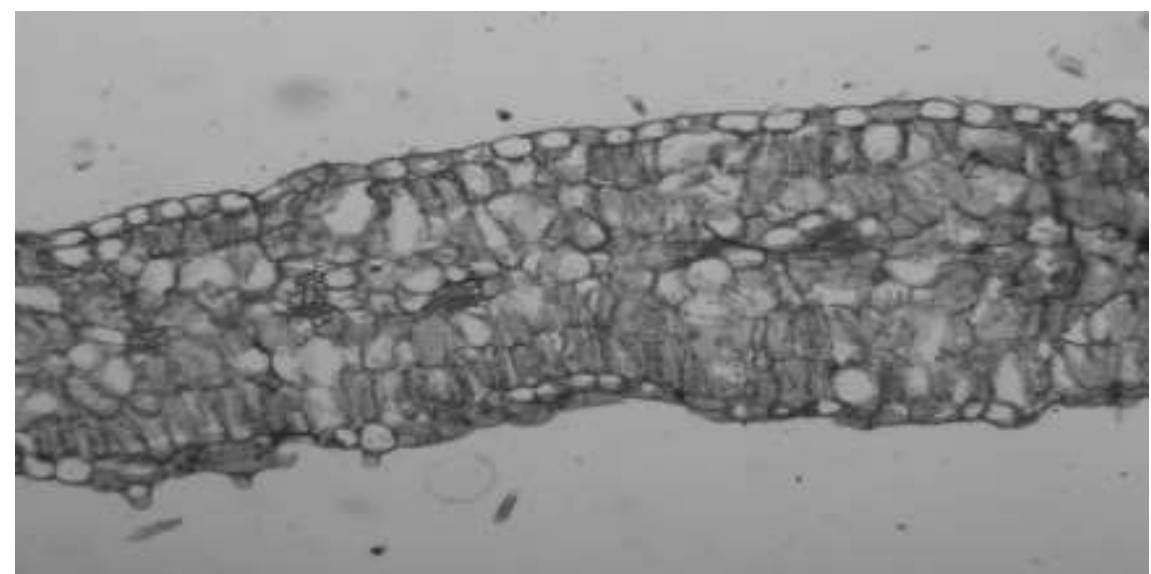

Fig.8. Light microscope study of section of infected leaf showing compact mesophyll (10X).

Egypt. J. Bot., 56, No. 2 (2016) 


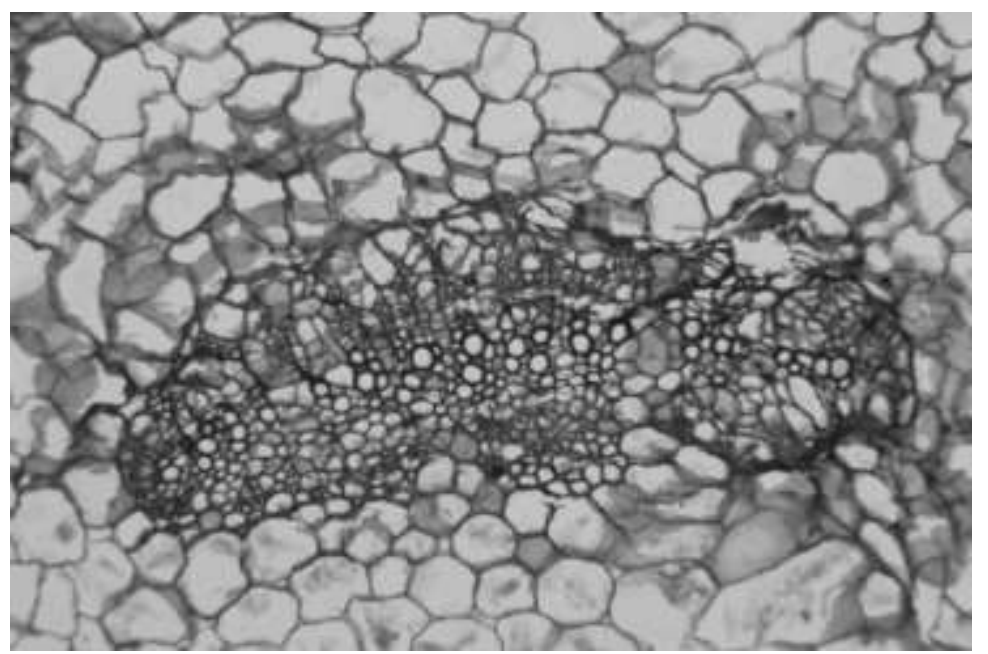

Fig.9. Light microscope study of section of infected leaf showing flat or slightly curved vascular bundle and necrotic tissues $(10 \mathrm{X})$.

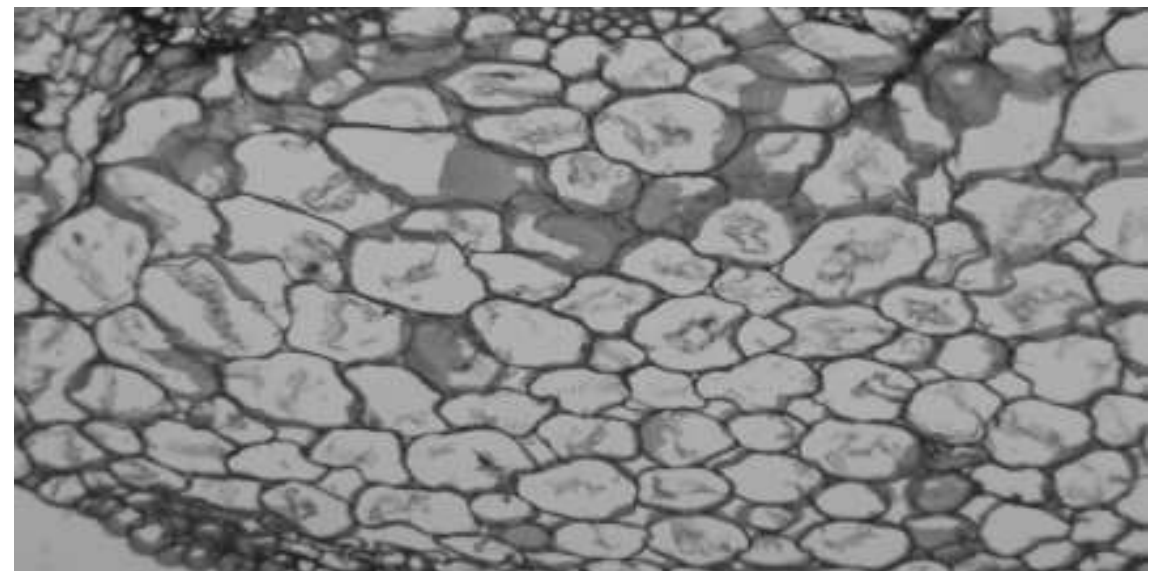

Fig. 10. Light microscope study of section of infected leaf showing large and wavy wall of parenchyma cells $(40 \mathrm{X})$.

Cytopathology of an Egyptian potyvirus isolate - infected Hyocyamus muticus L leaves .

Examination of ultrathin section of healthy $H$. muticus L. leaves showed healthy cells had cell wall with secondary depositions and contained normal nucleus, chloroplast and mitochondria (Figs. 11, 12, 13).

The results of ultrathin section of infected $H$. muticus L. leaves showed highly thickening of cell wall, cytoplasm appeared containing pinwheel (Figs. 14, 15) and scrolls inclusion bodies (Fig. 16).In some cell, the nucleus appeared flattened-shape (Fig. 17).The chloroplast became destroyed and deformed with undifferentiated thylakoid layers (Fig. 18).The mitochondria became aggregated with no special internal structure (Fig. 19). 


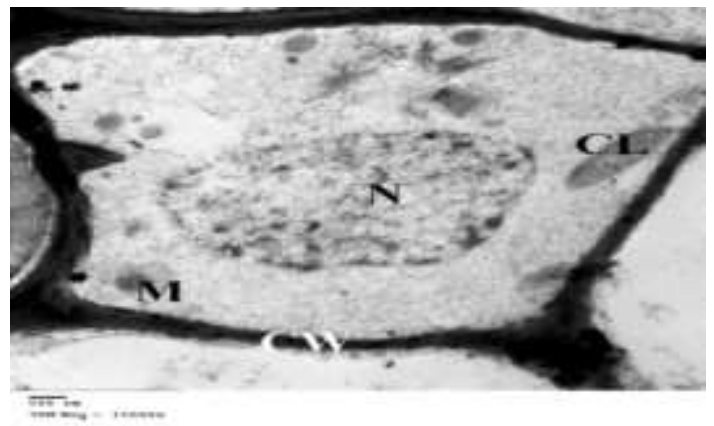

Fig.11. Electron micrograph of ultrathin section of cell of healthy Hyoscyamus muticus L. leaf showing normal thickness of cell wall $(\mathrm{CW})$, nucleus $(\mathrm{N})$, chloroplast (CL) and Mitochondria (M) (15.000X).

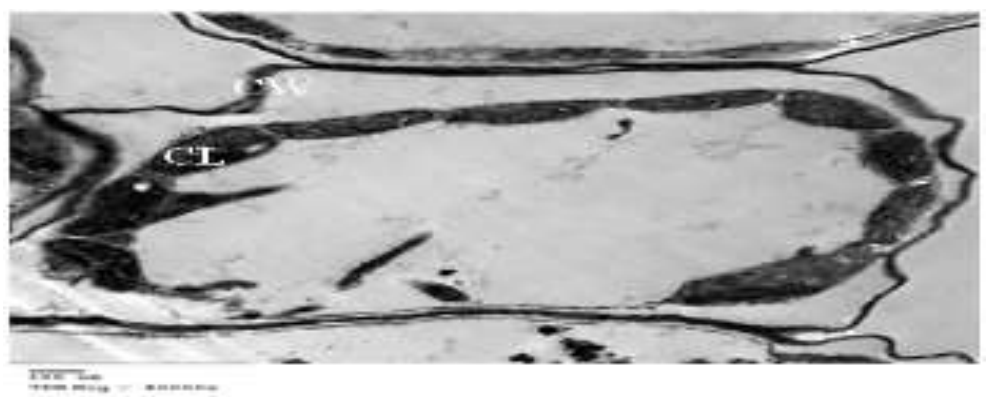

Fig.12. Electron micrograph of ultrathin section of cell of healthy Hyoscyamus muticus L. leaf showing many chloroplast (CL) and slightly thickened cell wall $(\mathrm{CW})(\mathbf{8 0 . 0 0 0 X})$

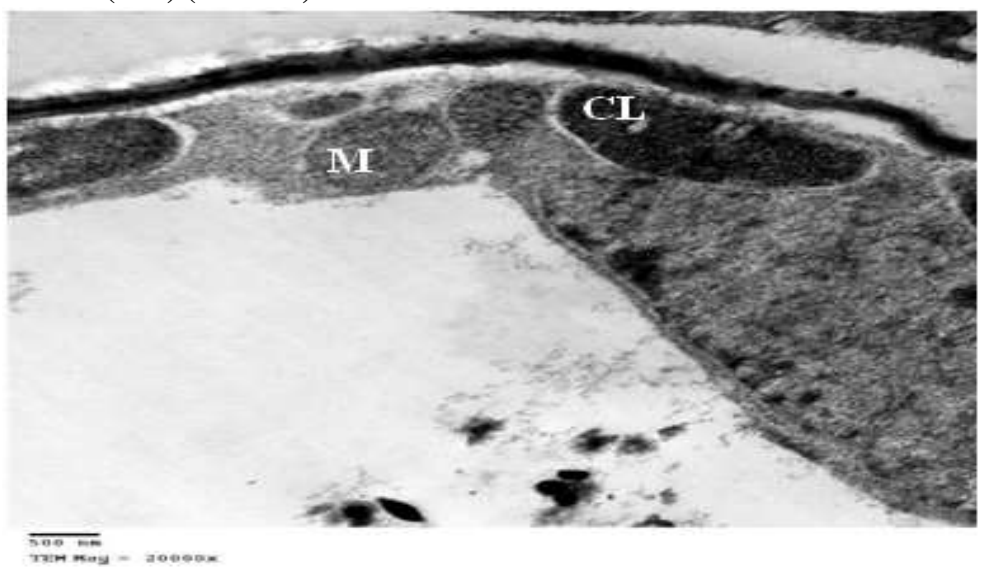

Fig.13. Magnified electron micrograph of ultrathin section of cell of healthy Hyoscyamus muticus L.leaf showing normal chloroplast (CL) and mitochondrion (M) (20.000X).

Egypt. J. Bot., 56, No. 2 (2016) 


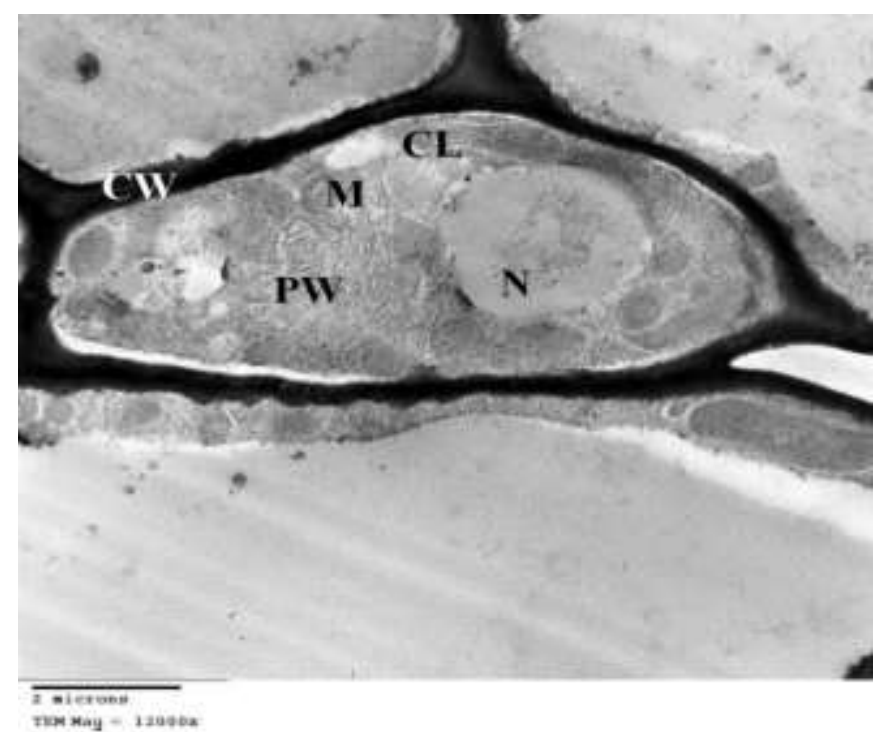

Fig.14. Electron micrograph of ultrathin section of cell of infected Hyoscyamus muticus $\mathrm{L}$. leaf showing the cell wall $(\mathrm{CW})$, nucleus $(\mathrm{N})$, chloroplast $(\mathrm{CL})$, Mitochondria (M) and pinwheel inclusion bodies (PW) (12.000 X).

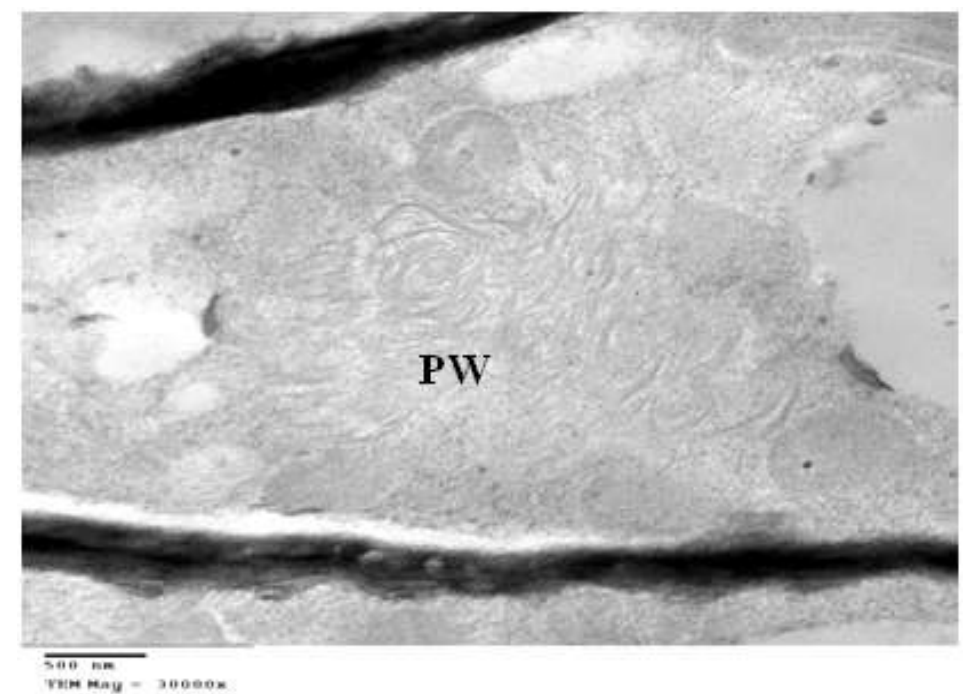

Fig.15. Magnified electron micrograph of ultrathin section of cell of infected Hyoscyamus muticus $\mathrm{L}$. leaf showing pinwheel (PW) (30.000X). 


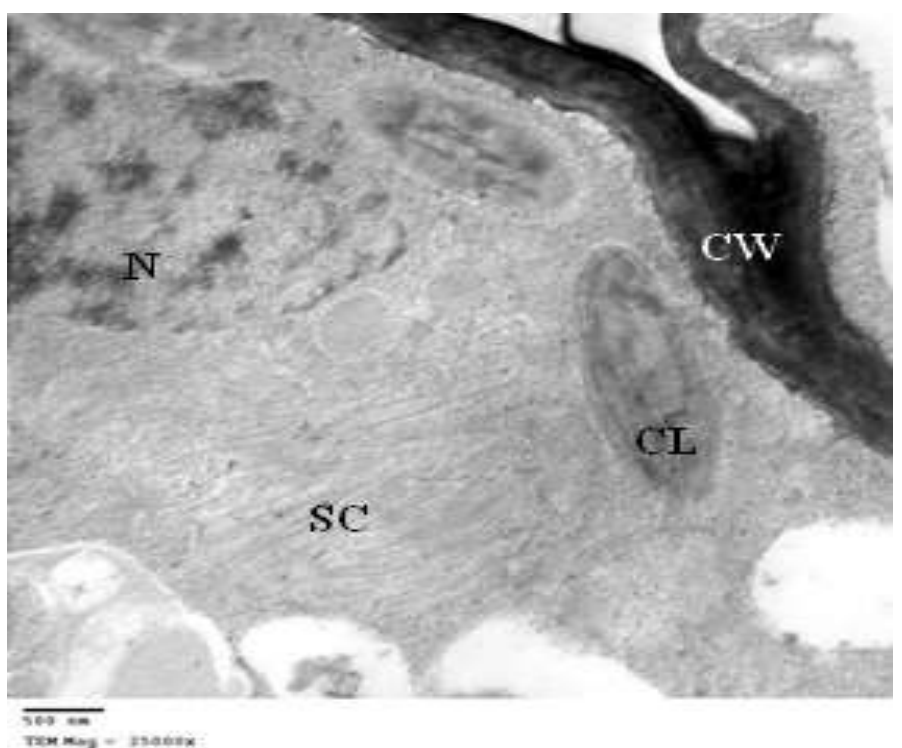

Fig.16. Electron micrograph of ultrathin section of cell of infected Hyoscyamus muticus L. leaf showing scrolls inclusion bodies (SC) (25.000X) .

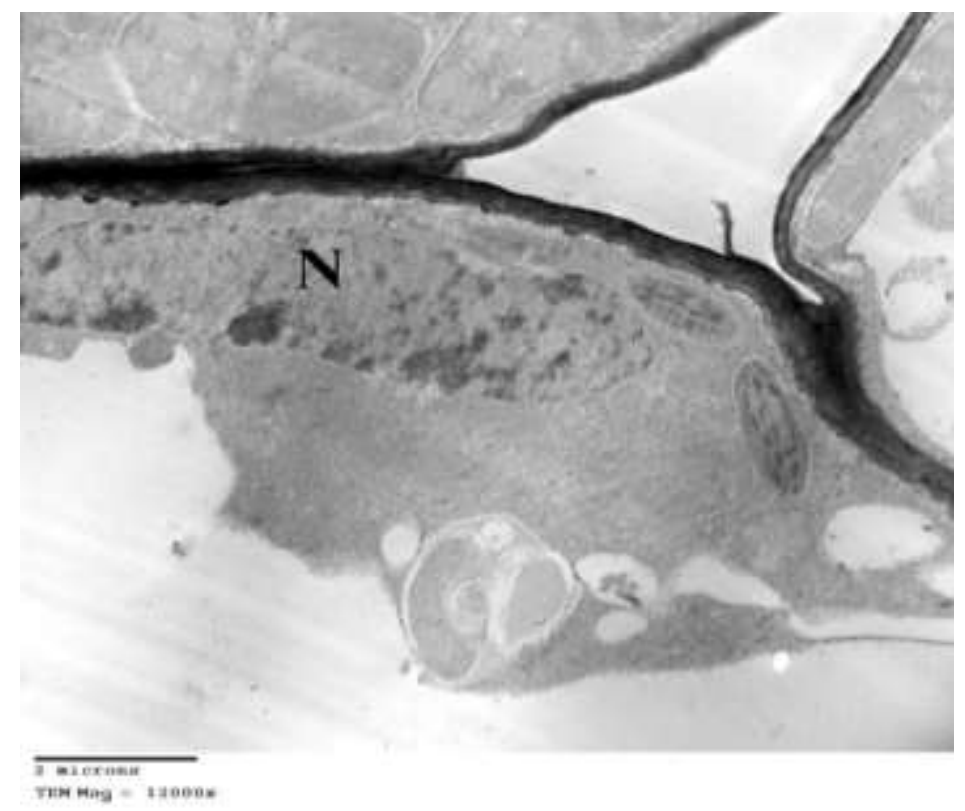

Fig.17. Electron micrograph of ultrathin section of cell of infected Hyoscyamus muticus $\mathrm{L}$. leaf showing flattened nucleus $(12.000 X)$. 


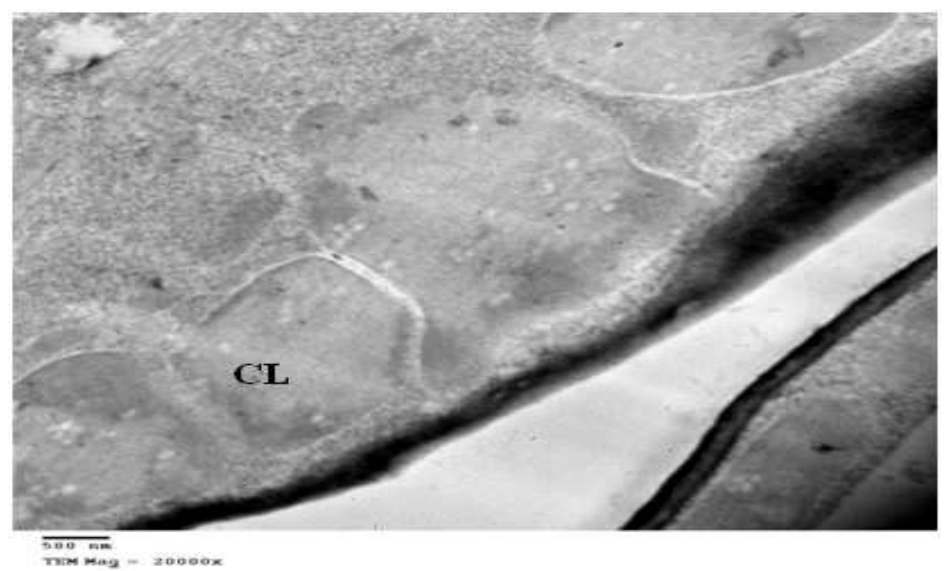

Fig.18. Electron micrograph of ultrathin section of cell of infected Hyoscyamus muticus L. leaf showing deformed chloroplast (CL) (20.000X).

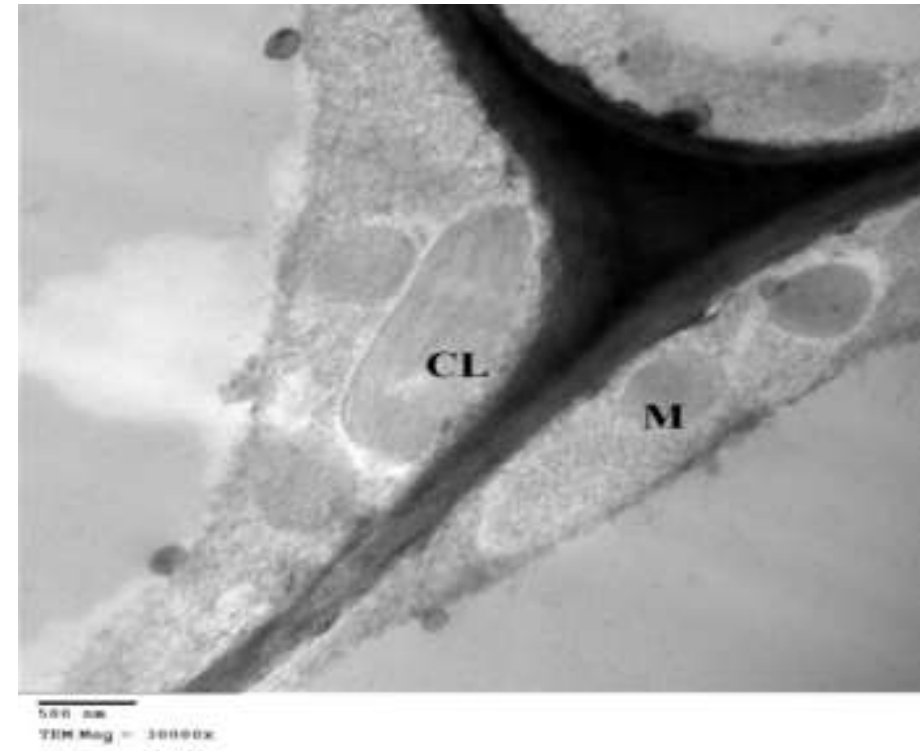

Fig.19. Electron micrograph of ultrathin section of cell of infected Hyoscyamus muticus L. leaf showing mitochondria (M) (30.000X)

\section{Discussion}

Plant viruses are one of the important large, highly different, and also economically important groups of plant pathogens, but which, despite their small size, can cause an enormous amount of pathological changes in plant cells (Gergerich and Dolja, 2006). 
The diverse range of microscopy techniques are universal tools in the identification of cytopathic changes in plant organ and tissue responses to viral infection. Light microscopy is the first developed method of microscopy, easily and widely applied in phytopathology research. Transmission Electron Microscopy (TEM) is the one of the most useful tool to investigate ultrastructure of plant cell as well as direct virus particle observation and its influence on cell organelles, which is closely related to the interaction between plant host and the virus infection (Otulak et al., 2014).

The histopathological studies of Hyoscyamus muticus L. leaves showed that the lamina of healthy leaf is nearly flat with slightly bulging midrib from other two sides; the upper and lower sides. Leaf blade has homogenous mesophyll tissue. The broad midrib contains a bicollateral vascular bundle. These results were in agreement with that obtained by Evans (2009) who reported that henbane leaves consist of very broad midrib with vascular bundle with bicollateral arrangement.

The lamina of infected $H$. muticus L. leaf with a new Egyptian potyvirus isolate (acc. No. KM497011) is mostly irregular with clearly bulging midrib from the upper and lower sides. Upper and lower epidermal cells are small in size and compact. Also, unequal thickness of blade appeared. In some parts, mesophyll tissue appears compact and spongy tissues between with very clear upper and lower palaside layers. In few parts, compact mesophyll tis sue shows no differentiation. These results were in agreement with that obtained by Ravinder Reddy et al. (2006) who showed that, the virus infection caused a reduction in the palisade parenchyma cells width so that the thickness of leaf blade is reduced. Upper epidermal layer are irregular than lower epidermal layer. Kunkalikar Suresh et al. (2005) showed that Papaya ring spot virus brings about histological changes in papaya upon infection. In infected leaves, palisade cells were markedly distorted. The spongy cells lost their normal round shape with complete disintegration.

The vascular bundle is somewhat flat or slightly curved bicollateral arrangement. The vascular bundle has haphazard arranged xylem vessels. Xylem vessels are nearly few in number and reduced in size. Upper and lower phloem patches not clearly recognized. The vascular bundle also showed abnormal necrotic regions. These results were similar to those obtained by IsHak and ElDeeb (2004) who observed the reduction in the xylem vessels diameter and phloem area as well as the leaf blades thickness in sweet potato leaves infected with Sweet potato chlorotic stunt virus.

Hinrichs et al. (1999) reported that the reaction between plant and virus infection as a biochemical aberration which is often accompanied by pathological changes on the cellular level (e.g., increased number of mitochondria, degeneration of chloroplasts, thickening of the cell wall), and eventually on the histological level that become macroscopically visible as symptoms.

Egypt. J. Bot., 56, No. 2 (2016) 
The cytopathological studies of infected $H$. muticus L. leaves with a new Egyptian potyvirus isolate showed highly thickening of cell wall, cytoplasm appeared containing pinwheel and scrolls inclusion bodies. These results were similar to those obtained by Sana et al. (1997) who detected cytoplasmic cylindrical inclusions of scrolls, pinwheels and curved laminated aggregates with elongated mitochondria at Henbane mosaic virus (HMV)- infected Datura metal leaf tissues. In addition to, Otulak and Garbaczewska (2012) found laminated inclusions in potato, pepper and tobacco tissues during infection with necrotic strains and the ordinary Potato virus Y strain. All potyviruses produce pinwheel inclusions, although laminated aggregate and scroll inclusions are also produced by some potyviral species (Hammond, 1998). Otulak and Garbaczewska (2012) stated that the presence of cytoplasmic inclusions usually in epidermal and mesophyll cell. It has become one of the important tools to identify the infection caused by potyviruses. Zechmann et al. (2003) reported that potyvirus infections are characterized by the presence of cytoplasmic inclusions that are composed of a putative RNA helicase and appear as bundles if cut longitudinally and as scrolls and pinwheels if cut transversely.

The nucleus of the infected host cells appeared flattened deformed-shape and the chloroplast of the infected host cells become destroyed and deformed with undifferentiated thylakoid layers. These results were in accordance to those obtained by Abou El-Ela et al. (2006) examined the carnation plants were infected with Carnation vein mottle potyvirus virus (CarVMV) using electron microscopy. It was appeared that, the nuclei were variable in shape and size, sometimes complete destruction of the nucleolus could be observed. Chloroplasts became disorganized, swollen, reduced and filled with vacuoles and clumped. Biswas and Varma (2006) found aggregation of chloroplasts around the nucleus in pumpkin plant infected with Watermelon mosaic potyvirus. Miller et al. (2003) and Jonczy et al. (2007) reported that different plant virus groups induce the formation of different cellular structures, both in shape and origin of organelle. These virus-induced cellular alterations are required for viral genome replication or for virus cell-to-cell movement.

Additionally, the mitochondria of the infected host cells become aggregated with no special internal structure. This result was in agreement with that obtained by Kitajima and Lovisolo (1972) who showed that there was an aggregate of numerous long, cylindrical mitochondria in thin sections of Datura stramonium L. leaf tissues infected by HMV and Saha et al. (1997) who detected aggregates with elongated mitochondria, in infected tissues of Datura metel with HMV.

\section{References}

Abou El-Ela, A.A., Amer, M.A. and Khatab, E.A.H. (2006) Cytological and molecular studies of an Egyptian isolate of Carnation vein mottle Potyvirus. Egyptian J.Virol.3, 1: $1-18$.

Biswas, C. and Varma A. (2006)Characterization of virus from pumpkin as an isolate of PRSV-W.Indian Phytopath. 59 (1), 101-104. 
Evans, W.C. (2009) "Trease and Evans Pharmacognosy", $16^{\text {th }}$ ed. Elsevier Saunders. 616 pp.

Gergerich, R.C. and Dolja, V.V. (2006) Introduction to plant viruses, the invisible foe. The Plant Health Instructor. DOI: 10.1094/PHI-I-2006-0414-01.

Hammond, J. (1998) Serological relationships between the cylindrical inclusion proteins of poty viruses.Phytopathology. 88: 965-971.

Hinrichs, B.J., Harfold, M. BergerS . and Buchenauer, H. (1999) Cytological responses of susceptible and extremely resistant potato plants to inoculation with Potato virus Y. Physiol. Mol. Plant Pathol. 44:143-150.

Horvath, J., Salamon, P., WolfI, and Kolber M. (1988) Henbane mosaic potyvirus pathogenic to wild and cultivated potato. Potato Res.31: 311-320.

IsHak, J. and El-Deeb, S. (2004)Investigating the effects of Sweetpotato Chlorotic Stunt Virus (SPCSV) infection to sweetpotato plants using light and electron microscopy. $J$ Plant Dis Protect. 111 (4): 362-370.

Johansen, D.A. (1940)General methods .In: "Plant Microtechnique", (Sinnot, E.W.,Ed.), McGrow-Hill Book Company, Inc., New York, NY, ,USA, pp.27-170.

Jonczyk, M., Pathak, K.B., Sharma, M. and Nagy, P.D. (2007) Exploiting alternative subcellular location forreplication: tombusvirus replication switches to the endoplasmic reticulum in the absence of peroxisomes. Virology.362(3):20-30.

King, A.M.Q., Adams, M.J., Carstens, E.B. and Lefkowitz, E.J. (2011) Virus taxonomy.Ninth report of the international committee on taxonomy of viruses. Elsevier Academic press, London, San Diego. pp.1326.

Kitajima, E.W. and Lovisolo, O. (1972) Mitochondrial aggregates in Daturaleaf cells infected with Henbane Mosaic Virus. J. Gen. Virol. X6: 265-271.

Kunkalikar, Suresh, Byadgi, A.S., Kulkarni, V. Krishna, Reddy, M. Prabhakar ASN. (2005) Histopathology and histochemistry of Papayaringspot disease in papaya. Indian. J. Virol.18(1): 33-35.

Miller, D.J. Schwartz, M.D., Dye, B.T. and Ahlquist, P. (2003) Engineered retargeting viral RNA replication complexes to an alternative intracellular membrane. J.Virol.77(22):12193-12202.

Otulak, K., Koziel, E. and Garbaczewska, G. ( 2014) Seeing is believing. The use of light, fluorescent and transmission electron microscopy in the observation of pathological changes during different plant - virus interactions.Microscopy: advances in scientific research and education (A. Méndez-Vilas, Ed.).367-376

Otulak, K. and Garbaczewska, G.(2012) Cytopathological Potato virus Y structures during Solanaceous plants infection. Micron.43: 839-850.

Purvis, M.J., Collier, D.C. and Walls, D. (1964) Preserving, fixing and embedding; section cutting and mounting; stains and staining techniques.In: Laboratory Techniques in botany (Butterworth and Co. Publishers, Ltd London, UK).pp.56-137.

Egypt. J. Bot., 56, No. 2 (2016) 
Ravinder, Reddy, Ch., Tonapi, V.A., Varanavasiappan, S., Navi, S.S. and Jayarajan R. (2006) Histopathological studies on Urdbean, Vigna mungo infected by Urdbean leaf crinkle disease. Indian J. Plant Prot. 34(1): 62-65.

Revers, F. and García J.A. (2015) Molecular biology of poty viruses. Advances in Virus Research. 92: 101-199.

Reynolds, E.S. (1963) The use of lead citrate at high $\mathrm{pH}$ as an electron-opaque stain in electron microscopy. J. Cell Biol. 17: 208-212.

Saha, S., Varma, A. and Jain, R.K. (1997) Biological and N-terminal serological properties of a strain of henbane mosaic virus causing mosaic disease of Datura metel Linn. Trop. Agric. Res. 9: 346-357.

Sass, J.E. (1951) "Botanical microtecqnique". ${ }^{\text {nd }}$ ed. Ames, Iowa: The Iowa state college press building. $228 \mathrm{pp}$.

Shukla, D.D., Ward, C.W. and Bunt, A.A. (1994) "The Potyviridae.C.A.B. International", Wallilngford, UK.

Stockem, W. and Komnick, H. (1970) Electron microscopic demonstration of epithelial surfaces using a surface-reproduction technic. Mikroskopie. 26(5):190-198.

Yamamoto, H. and Fuji, S. (2008) Rapid determination of the nucleotide sequences of poty viral coat protein genes using semi-nested RT-PCR with universal primers. J. Gen. Plant Pathol. 74(2):97-100.

Zechmann, B., Muller, M. and Zellnig, G. (2003) Cytological modifications in zucchini yellow mosaic virus (ZYMV)-infected Styrian pumpkin plants. Arch.Virol. 148: 11191133.

(Received 6/12/2015; accepted 17/1/2015) 


\section{تغيرات خلوية و نسيجية مستحثة بواسطة عزلة جديدة لفيروس} البوتي علي أوراق نبات السكران نوينة

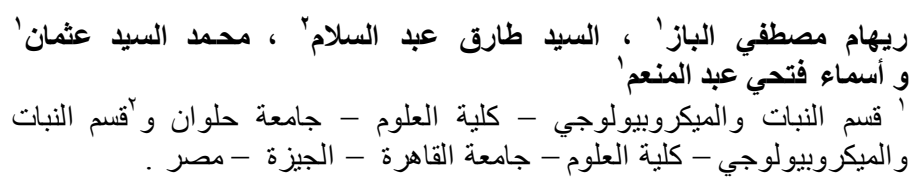

تم دراسة التغيرات الخلوية و النسيجية علي نبات السكران المصاب بالعزلة

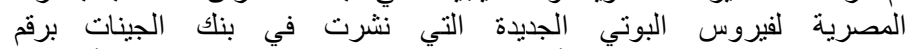

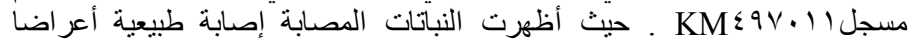

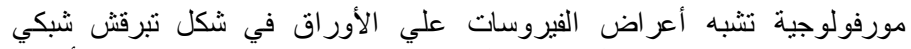

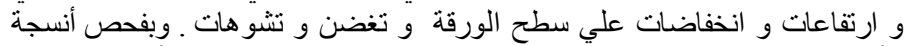

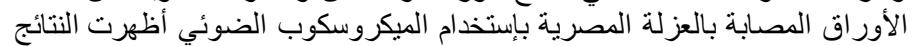

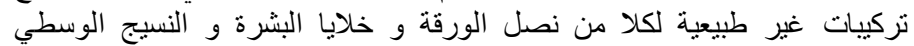

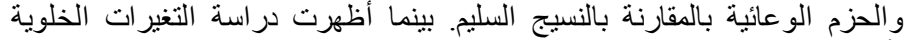

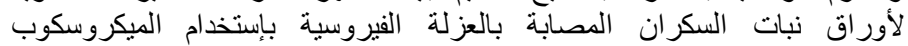

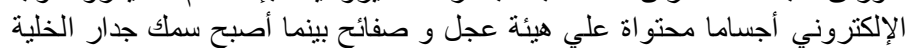

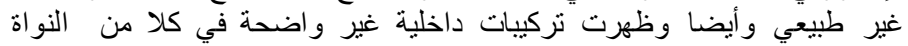

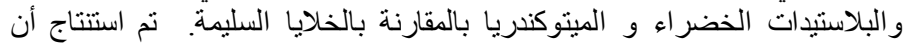

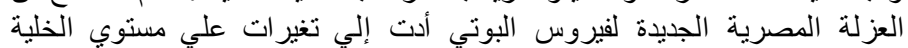

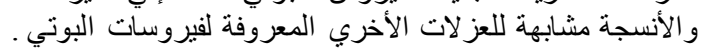

